\section{Aquatic Toxicology}

Vol. 78, Issue 2 , 15 June 2006, Pages 149-156

http://dx.doi.org/10.1016/j.aquatox.2006.02.028

(c) 2006 Elsevier B.V. All rights reserved.
Archimer, archive institutionnelle de l'Ifremer http://www.ifremer.fr/docelec/

\title{
Effects of cadmium on aneuploidy and hemocyte parameters in the Pacific oyster, Crassostrea gigas
}

\author{
Karine Bouilly $^{\mathrm{a}, 1}$, Béatrice Gagnaire ${ }^{\mathrm{a}}$, Marc Bonnard ${ }^{\mathrm{a}}$, Hélène Thomas-Guyon ${ }^{\mathrm{b}}$, Tristan \\ Renault $^{\mathrm{a}}$, Pierre Miramand ${ }^{\mathrm{b}}$ and Sylvie Lapègue ${ }^{\mathrm{a}, \text { * }}$
}

\begin{abstract}
aFREMER, Laboratoire de Génétique et Pathologie, La Tremblade 17390, France
baboratoire de Biologie et Environnement Marins, FRE-CNRS, 2727, Université de La Rochelle, 22 Avenue Michel Crépeau, La Rochelle 17042, France

*: Corresponding author : Tel.: +33 5467626 31; fax: +33 5467626 11; email : slapegue@ifremer.fr

1 : Present address: University of Trás-os-Montes and Alto Douro, Centre of Genetics and Biotechnology, Vila Real 5000-911, Portugal.
\end{abstract}

\begin{abstract}
:
Pacific oysters, Crassostrea gigas, are commonly reared in estuaries where they are exposed to anthropogenic pollution. Much research has been made on the toxicity of cadmium to aquatic organisms because the compound recurrently contaminates their environment. Our study examined the influence of cadmium on aneuploidy level (lowered chromosome number in a percentage of somatic cells) and hemocyte parameters in C. gigas at different stages of life. Adults and juveniles were exposed to two different concentrations of cadmium. The first concentration applied was equivalent to a peak value found in Marennes-Oléron bay (Charente-Maritime, France; $50 \mathrm{ng} \mathrm{L}^{-1}$ ) and the second was 10 times higher $\left(500 \mathrm{ng} \mathrm{L}^{-1}\right)$. Exposure to $50 \mathrm{ng} \mathrm{L}^{-1}$ cadmium caused a significant decrease in the survival time of $C$. gigas, but exposure to $500 \mathrm{ng} \mathrm{L}^{-1}$ surprisingly affected the survival time positively. Significant differences in aneuploidy level were observed between the cadmium treatments and the control in adults but not in juveniles or the offspring of the adult groups. The effects of cadmium on hemocyte parameters were analyzed by flow cytometry. Several hemocyte parameters increased significantly after 21 days of cadmium exposure and subsequently decreased. Phenoloxidase-like activity, evaluated by spectrophotometry, varied over the time of the experiment and increased after 66 days of contact with $500 \mathrm{ng} \mathrm{L}^{-1}$ cadmium. Taken together, cadmium at environmentally relevant concentrations seems to have only moderate effects on aneuploidy and hemocyte parameters.
\end{abstract}

Keywords: Cadmium; Crassostrea gigas; Aneuploidy; Hemocytes; Flow cytometry; Phenoloxidase 


\section{Introduction}

The Pacific oyster, Crassostrea gigas, is the most economically valuable mollusk species in the world (FAO, 2004). This species is often reared in coastal ecosystems where pollutants degrade environmental quality.

C. gigas has a diploid chromosome number of $2 n=20$ (Thiriot-Quiévreux, 1986) but hypodiploid aneuploid cells $(2 n<20)$ are commonly found and the percentage of somatic cells affected by this phenomenon is negatively correlated with growth rate (Leitão et al., 2001a). Evidence suggests that genetic background influences the level of aneuploidy in C. gigas (Leitão et al., 2001b) and that certain environmental contaminants (the herbicides atrazine and diuron) increases it (Bouilly et al., 2003; 2004; unpublished). Different chromosomes are differently susceptible to aneuploidy (Leitão et al., 2001c; Bouilly et al., 2005).

The open circulatory systems of mollusks are continually exposed to fluctuations of environmental factors including contaminants (Cheng, 1981). In bivalves, the cellular defense system consists of hemocytes which have various modes of action including phagocytosis, intracellular degradation of pathogens with hydrolytic enzymes, production of reactive oxygen metabolites and phenoloxidase activity (Cheng and Rodrick, 1975; Cheng, 1988a; Pipe, 1992).

Cadmium pollution is a concern because of both environmental and occupational reasons, since it has a wide variety of adverse effects. The presence of cadmium in Marennes-Oléron bay, France (Charente-Maritime) (Boutier et al., 1989; Pigeot et al., 2006) could cause significant problems as this is the largest oyster rearing area in Europe (30,000-40,000 metric tons produced annually, Soletchnik et al., 2001). Cadmium has an extremely long biological half-life, essentially making it a cumulative toxin. It has been classified as a human carcinogen and is a potent multi-tissue animal carcinogen (IARC, 1993). Most bivalve mollusks are filter feeders and concentrate cadmium and other metals in their soft tissues.

Although many studies have been made on cadmium accumulation by bivalves and its toxic effects on them (e. g. Watling, 1978; Zaroogian and Morrison, 1981; Miramand et al., 1999; Pennec et al., 2002), few investigations have studied its genotoxicity or immunotoxicity to these organisms.

The aim of the present study was to focus on the genotoxic and immunological effects of cadmium on the Pacific oyster at environmentally representative concentrations. We looked at whether cadmium had any effect on chromosome number at two different stages of development (adult and juvenile) and on a subsequent generation. Hemocyte parameters (cell mortality, phagocytosis, esterase, peroxidase and aminopeptidase activities) were monitored by flow cytometry in the same population of adult oysters. Phenoloxidase-like activity was also measured using spectrophotometry.

\section{Materials and methods}

\subsection{Biological material}

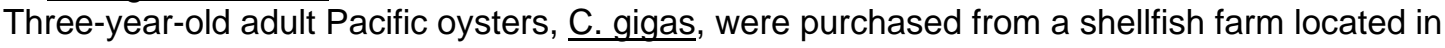
Marennes-Oléron bay (La Tremblade, Charente-Maritime, French Atlantic coast) in March 2002. In the same period, other oysters were bred and raised to the juvenile (spat) stage at the IFREMER (Institut Français de Recherche pour l'Exploitation de la Mer) hatchery in La Tremblade.

\subsection{Cadmium exposure}

Both adults and juveniles were exposed to cadmium by adding cadmium solutions to seawater pumped from Marennes-Oléron bay. Ordinary seawater was used as a control (treatment 1). The cadmium treatments represent the peak value found at the north of Marennes-Oléron bay in 1991 (50 $n ~^{-1}$ ) (treatment 2) (Boutier et al., 2000), and a value ten times higher (500 $\mathrm{ng} \mathrm{L}^{-1}$ ) (treatment 3). Two replicates $(A$ and $B$ ) were made for each concentration and for the control.

For the experiment on adults, each raceway contained 70 oysters $(\sim 70-\mathrm{mm}$ shell length) for the aneuploidy study and 50 oysters for monitoring hemocyte parameters. These oysters were first acclimated to the hatchery environment for 14 days in through-flow raceways. The experiment was then conducted over two months in closed-circuit raceways equipped with water circulation systems for oxygenation. Each raceway contained $125 \mathrm{~L}$ of seawater which was changed every day and maintained at $19.5^{\circ} \mathrm{C} \pm 1^{\circ} \mathrm{C}$. Cadmium solutions, made by dissolving the initial solid cadmium chloride (anhydrous $\mathrm{CdCl}_{2}$, Sigma) in distilled water, were added to the raceways of treatments 2 and 3 every day. The treatment doses were $125 \mathrm{~mL}$ cadmium at $50 \mu \mathrm{g} \mathrm{L}^{-1}$ for treatment 2 and $125 \mathrm{~mL}$ at $500 \mu \mathrm{g} \mathrm{L}$ ${ }^{1}$ for treatment 3 . All cadmium treatments were diluted in $5 \mathrm{~L}$ of seawater before they were added to the raceways. The oysters were fed daily with a mixture of algae (Skeletonema costatum, Isochrysis galbana, Tetraselmis suecica, and Chaetoceros calcitrans).

The experiment with juveniles was performed separately as the juveniles were produced after adult exposure began. At the age of 2 months, groups of 150 juveniles ( $5-\mathrm{mm}$ shell length) were 
placed in six aquariums. No acclimation was necessary as these animals had always been kept in the hatchery. The experiment was conducted over three and a half months in closed-circuits with systems of water circulation for oxygenation. Each aquarium contained $16 \mathrm{~L}$ of seawater, to which $16 \mathrm{~mL}$ of cadmium at $50 \mathrm{\mu g} \mathrm{L}^{-1}$ was added for treatment 2 and $500 \mathrm{~g} \mathrm{~L} \mathrm{~L}^{-1}$ for treatment 3. Seawater and cadmium were changed daily and the juvenile oysters fed with I. galbana. Mortality was monitored in both adult and juvenile populations.

\subsection{Offspring of exposed adults}

At the end of the two month exposure period, six males and six females from each treatment were crossed. Gametes were obtained by strip-spawning sexually mature animals. For each fertilization, 600 million spermatozoids were added to approximately 3 million oocytes suspended in 1 $\mathrm{L}$ of seawater. The fertilized gametes were divided into two replicates for each cross and these were placed in 30-liter fibreglass larval tanks of seawater. Larvae were reared for approximately 3 weeks under standard conditions $\left(30 \mathrm{~L}\right.$ tanks, temperature: $\left.23-24^{\circ} \mathrm{C}\right)$ and fed with a mixture of phytoplankton

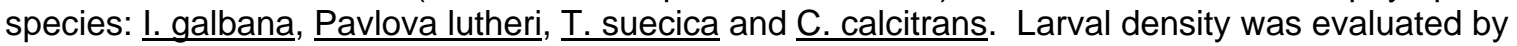
microscope counts of samples from each batch. Larval growth was studied by measuring the size of 50 larvae per batch every two or three days on an image analysis system. The larvae were transferred to a micro-nursery when they were ready to settle. Aneuploidy of these offspring was studied at eight months.

\subsection{Chromosome preparation for aneuploidy analysis}

Aneuploidy level was studied in all groups: adults and juveniles from the exposure experiments, and the offspring of the adults. The oysters were first incubated for 7-8 $\mathrm{h}$ in seawater containing $0.005 \%$ colchicine. Their gills were then dissected in a dish of seawater, treated for 40 minutes in $0.9 \%$ sodium citrate and fixed in a freshly prepared mixture of 3:1 absolute ethanol-acetic acid (four changes: $10 \mathrm{~min}, 10 \mathrm{~min}, 20 \mathrm{~min}, 20 \mathrm{~min}$ ). Each slide was made from a piece of gill tissue following the air drying technique of Thiriot-Quiévreux and Ayraud (1982). The slide preparations were stained for 10 min with Giemsa (4\%, pH 6.8).

\subsection{Aneuploidy scoring}

Chromosome counts were made by microscope observation (Olympus $\mathrm{BH} 2$ microscope) on apparently intact and well-spread metaphase cells. We considered the cells with $2 n=19,18$ or 17 chromosomes as aneuploid. The mean percentage aneuploidy per replicate was estimated by counting 30 metaphase cells per animal in 10 animals per replicate (300 well-spread metaphase cells per replicate in total).

\subsection{Sampling of circulating hemocytes}

Adult oyster hemocytes were collected at $0,4,21,39$ and 66 days. On each occasion, ten oysters were analyzed per raceway. Hemolymph was withdrawn from the pericardial cavity using a 1$\mathrm{mL}$ syringe equipped with a needle $(0.9 \times 25 \mathrm{~mm})$. For each oyster, $0.5-1 \mathrm{~mL}$ of hemolymph was collected and conserved on ice to prevent hemocyte aggregation. Hemolymph samples were pooled from five oysters, giving two pools per raceway and four pools per treatment.

\subsection{Cell analysis by flow cytometry}

Flow cytometry protocols were used as described in Gagnaire et al. (2003; 2004). For each sample, 3,000 events were counted using an EPICS XL 4 flow cytometer (Beckman Coulter). Results were expressed as cell cytograms indicating the size (FSC value), complexity (SSC value) and fluorescence channel(s) corresponding to the marker used. The type of fluorescence recorded depended on the parameter monitored: enzymes and phagocytosis were measured using FL1 and mortality using FL3.

Mortality was quantified using $200 \mu \mathrm{L}$ hemolymph. Hemocytes were incubated in the dark for 30 min at $4^{\circ} \mathrm{C}$ with $5 \mu \mathrm{L}$ propidium iodide (PI, $1.0 \mathrm{mg} \mathrm{mL}^{-1}$, Interchim). Esterase, aminopeptidase and peroxidase activities were evaluated with commercial kits (Cell Probe ${ }^{\mathrm{TM}}$ Reagents, Beckman Coulter). Each analysis required $200 \mu \mathrm{L}$ hemolymph and $20 \mu \mathrm{L}$ of the corresponding kit (FDA•Esterase, $\mathrm{A} \bullet$ Aminopeptidase $\mathrm{M}$ and DFCH or PMA•Oxidative Burst). Hemocytes were incubated in the dark at room temperature for $15 \mathrm{~min}$ for esterases and peroxidases and for $30 \mathrm{~min}$ for aminopeptidases. Phagocytosis was measured by ingestion of fluorescent beads. Two hundred $\mu \mathrm{L}$ of hemolymph was incubated for $1 \mathrm{~h}$ in the dark at room temperature with $10 \mu \mathrm{L}$ of a $1 / 10$ dilution of Fluorospheres ${ }^{\circledR}$ carboxylate-modified microspheres (diameter $1 \mu \mathrm{m}$, Interchim). 


\subsection{Phenoloxidase-like (PO-like) activity detection}

Hemolymph samples were centrifuged $\left(260 \mathrm{~g}, 10 \mathrm{~min}, 4^{\circ} \mathrm{C}\right)$ and the acellular fraction

(supernatant) was frozen at $-20^{\circ} \mathrm{C}$ for further analysis. Detection of PO-like activity in acellular fraction samples was carried out by measurement of L-Dopa transformation in dopachromes. Transformation was monitored by spectrophotometry at $490 \mathrm{~nm}$. The hemolymph samples were placed in 96 well microplates with $20 \mu \mathrm{L}$ in each well. Purified trypsin TPCK (N-Tosyl-I-phenylalanine chloromethyl ketone, $1 \mathrm{~g} \mathrm{~L}^{-1}$, Sigma) was used as an activator of PO activity. Phenylthiourea PTU (1-Phenyl-3-(2Thiazolyl)-2-Thiourea, $10 \mathrm{mM}$, Sigma), was used as an inhibitor of $\mathrm{PO}$ activity. The following reagents were added to each cell: $60 \mu \mathrm{L}$ cacodylate buffer (CAC), $20 \mu \mathrm{L}$ PO activity modulator (TPCK or PTU), $20 \mu \mathrm{L} \mathrm{L-Dopa} \mathrm{(L-3,} \mathrm{4-dihydroxyphenylalanine,} 3 \mathrm{mg} \mathrm{mL}^{-1}$, Sigma).

\subsection{Statistical analysis}

Since the number of metaphase cells evaluated per individual was the same in all the studied material (30 per individual), it was possible to test the replicate effect using a two-way analysis of variance (cadmium concentration and replicate effect). Results were compared between parents and offspring using a three-way analysis of variance in which the effects were generation (parents or offspring), cadmium concentration and replicate effect. Analyses of variance were made using SYSTAT 9.0 by SPSS (Wilkinson, 1990).

Survival rates of oysters were examined using the Kaplan-Meier method (Kaplan and Meier, 1958). The Mantel-Cox test (also known as the log-rank test) was used to compare survival trends between oysters exposed to different cadmium treatments (Mantel, 1966). Effect of parental treatment on offspring hatching rate was analyzed with G-tests (Scherrer, 1984; Sokal and Rohlf, 1995). Larval growth curves were compared using correlation coefficients $(R)$.

Hemocyte parameter values were analyzed using non-parametric Kruskall-Wallis tests. $\mathrm{H}_{0}$ was rejected when $\mathrm{P} \leq 0.05$. In the cases where $\mathrm{H}_{0}$ was rejected, an a posteriori Student-Newman-Keuls (SNK) test was used.

\section{Results}

\subsection{Survival and development parameters}

For adult oysters exposed to 0,50 , and $500 \mathrm{ng} \mathrm{L}^{-1}$ cadmium, mortality rates were $27.1 \%, 39.3 \%$, and $17.9 \%$ respectively. For juvenile oysters exposed to 0,50 , and $500 \mathrm{ng} \mathrm{L}^{-1}$ cadmium, mortality rates were $23.3 \%, 33 \%$, and $15.7 \%$ respectively. Survival curves are presented in Fig. 1 and Fig. 2 for adult and juvenile oysters, respectively. For adult oysters, the difference was statistically significant between treatments 1 and 2 (Mantel-Cox $=5.71 ; P=0.0169$ ) and between treatments 2 and 3 (Mantel-Cox $=14.2 ; \mathrm{P}=0.0002$ ). No significant survival difference was observed between treatments 1 and 3 though (Mantel-Cox $=2.62 ; \mathrm{P}=0.1055)$. For juvenile oysters, significant differences were observed between treatments 1 and 2 (Mantel-Cox $=5.364 ; \mathrm{P}=0.0206$ ), treatments 2 and 3 (MantelCox $=24.513 ; \mathrm{P}<0.0001$ ), and treatments 1 and 3 (Mantel-Cox $=6.194 ; \mathrm{P}=0.0128$ ).

Abnormally high mortality occurred in the larval offspring replicate $1 \mathrm{~A}$ due to a technical problem with oxygenation the first day. This probably contributed to the low hatching rate (41\%) compared with the other larval tanks. This result was therefore not used in the calculation of hatching rates per treatment. Where the parents were exposed to 0,50 , and $500 \mathrm{ng} \mathrm{L}^{-1}$ cadmium, the hatching rates were $70.3 \%, 74.8 \%$, and $94.5 \%$ respectively and were not significantly different ( $G=4.059)$. The offspring of parents from the different treatments did not show any significant differences in their larval growth either (Fig. 3). R-values for growth of progenies of treatments 1, 2 and 3 were 1.000, 0.9998 and 0.9999 respectively.

\subsection{Aneuploidy}

Aneuploidy levels of adult oysters in the replicates of treatments 1 (control), 2 (50 $\mathrm{ng} \mathrm{L}^{-1}$ ) and 3 (500 $\mathrm{ng} \mathrm{L}^{-1}$ ) produced means of 13.3 and $16.3 \%, 18$ and $22.7 \%$, and $23.7 \%$ (both replicates) respectively (Fig. 4). Treatment effect was highly significant $(P<0.001)$ but replicates were not significantly different $(P=0.740)$. Considering pairs of treatments, significant differences were observed between treatments 1 and $2(P=0.007)$ and between 1 and $3(P<0.001)$ but not between 2 and $3(P=0.084)$.

Aneuploidy levels of juvenile oysters were significantly lower than those of adults $(P<0.001)$. Juvenile aneuploidy levels in the replicates of treatments 1 (control), $2\left(50 \mathrm{ng} \mathrm{L}^{-1}\right)$ and $3\left(500 \mathrm{ng} \mathrm{L}^{-1}\right)$ produced means of 12.7 and $15 \%, 14.7$ and $15.7 \%$, and 14.3 and $19.3 \%$ respectively (Fig. 4). There were no significant differences between replicates $(P=0.405)$ or treatments $(P=0.250)$. 
When treatments were compared two by two (adults and juveniles together), we observed significant differences between the treatments $(P=0.017 ; P<0.001 ; P=0.040$ for the treatments 1 and 2, 1 and 3, and 2 and 3 respectively). Differences between adult and juvenile oysters were also found in the treatment pairs $(P=0.031 ; P=0.005 ; P<0.001$ for the treatments 1 and 2,1 and 3 , and 2 and 3 respectively).

Offspring aneuploidy levels in the replicate groups of progeny from treatments 1,2 and 3 produced means of 9.7 and 13.3\%, 9.7 and $13.7 \%$, and 9.7 and $13.3 \%$ respectively (Fig. 4). As with the exposed juveniles, neither replicate $(P=0.424)$ or treatment $(P=0.996)$ had a significant effect. When parents and offspring were analyzed together, there was no significant replicate effect $(P=$ $0.422)$ but significant differences were found for treatment $(P=0.010)$ and between parents and offspring $(P<0.001)$. Analysis of pairs of treatments showed that only treatments 1 and 3 were significantly different $(P=0.001)$.

\subsection{Hemocyte parameters}

Hemocyte parameters were analyzed in the adults at $0,4,21,39$ and 66 days. Values of these parameters evolved over time for any one treatment considered. Hemocyte mortality and percentages of esterase and peroxidase positive cells increased until 21 days and then decreased in subsequent samples $(P<0.05$, Table 1). The largest inter-treatment differences occurred at 21 days (Fig. 5). Percentages of esterase and peroxidase positive cells only increased significantly at $500 \mathrm{ng} \mathrm{L}^{-1} \mathrm{Cd}$. Phagocytosis decreased significantly at $50 \mathrm{ng} \mathrm{L}^{-1}$ (Fig. 5).

\subsection{Evolution of PO-like activity in acellular fractions}

PO-like activity in hemolymph was detected both in the absence and presence of cadmium. It varied over the time of experiment, with a maximum at 39 days and minima at 21 and 66 days (Fig. 6). No effect of cadmium was observed on PO-like activity except after 66 days of contact. Activity increased at $500 \mathrm{ng} \mathrm{L}^{-1}$ cadmium $(P<0.05$, Table 1$)$.

\section{Discussion}

\subsection{Survival and developmental parameters}

Treatment had a significant effect on survival though results were not dose-dependant. Survival time decreased when oysters were maintained in contact with $50 \mathrm{ng} \mathrm{L}^{-1}$ cadmium, compared with the control, but increased at $500 \mathrm{ng} \mathrm{L}^{-1}$. Adults and juveniles both showed this pattern and this could have arisen from a secondary effect of cadmium on bacterial populations. Bacteria have some cadmium tolerance and certain types can develop mechanisms of detoxification (Ivanova et al., 2002). Following chronic exposure to sublethal toxin concentrations, anoxic survival generally decreases (de Zwaan and Eertman, 1996). Such a decrease was shown when the bivalve Scapharca inaequivalvis was exposed to $100 \mathrm{\mu g} \mathrm{L}^{-1}$ cadmium for two weeks. However, when $\underline{\mathrm{S} \text {. inaequivalvis and Venus }}$ gallina were exposed to a dose of cadmium 5 times higher, anoxic survival time increased by a factor of 2 (de Zwaan et al., 2001). Cadmium effects could be enhanced by the presence of other pollutants. Two $\mathrm{mg} \mathrm{L}^{-1}$ of $\mathrm{Cd}$ and $150 \mathrm{\mu g} \mathrm{L}^{-1}$ of Cu caused higher mortality than $\mathrm{Cd}$ at $2 \mathrm{mg} \mathrm{L}^{-1}$ in Ostrea edulis (Auffret et al., 2002).

Robert and His (1985) observed that cadmium concentration in the Gironde estuary $\left(1 \mathrm{gg} \mathrm{L}^{-1}\right)$ did not affect the breeding potential of $\mathrm{C}$. gigas. This result agrees with the present study since our lower cadmium concentrations ( 50 and $500 \mathrm{ng} \mathrm{L}^{-1}$ ) did not reduce breeding success in the crosses we made, nor did these concentrations of cadmium in the parental environment have an effect on offspring larval growth. In another previous study, Watling (1978) only observed a decrease in C. gigas larval growth with higher concentrations (from $20 \mathrm{\mu g} \mathrm{L}^{-1}$ ). Moreover, Robert and His (1985) observed no effect on the larval development of the same species below $50 \mathrm{\mu g} \mathrm{L}^{-1}$. When parental oysters were exposed to atrazine, this herbicide affected the hatching rate of offspring but not subsequent larval growth (Bouilly et al., 2004). The presence of diuron in the parental environment did not affect offspring hatching rate or larval growth though (Bouilly et al., unpublished).

\subsection{Aneuploidy}

Cadmium was seen to affect aneuploidy when adult oysters were exposed to 50 and $500 \mathrm{ng} \mathrm{L}^{-1}$. This effect was not shown in juvenile oysters even though they were exposed to cadmium for slightly longer. This may be because juvenile oysters are less sensitive to cadmium than adult oysters. Although we know of no previous studies that compared juveniles and adults, Vicente et al. (1988) showed that earlier stages (eggs and larvae) were more sensitive to cadmium than adults. However, many studies on toxicity to larvae only showed effects on development at levels of 5 to $20 \mu \mathrm{g} \mathrm{L}^{-1}$ 
cadmium (Zaroogian and Morrison, 1981; Watling, 1978) and Robert and His (1985) found no effect even at $50 \mu \mathrm{g} \mathrm{L}^{-1}$.

The offspring of the adult oysters from the exposure experiment were not significantly different between groups originating from adults from the different cadmium treatments. Aneuploidy levels of these offspring were, however, lower than those of their parents. This study therefore provides no evidence that cadmium-induced aneuploidy effects persist to the next generation. This contrasts with results observed in similar experiments on atrazine (Bouilly et al., 2004) and diuron (Bouilly et al., unpublished), where heritable effects were observed. These two herbicides probably have different mechanism/s of action to cadmium. Although the impact of cadmium on adult aneuploidy was higher than that of these other contaminants under the concentrations studied, it did not seem to affect the sex cells. Atrazine and diuron must have some impact on reproductive tissues to have mediated the effects observed in the offspring. The present results also contrast with evidence for family effects on the control of aneuploidy shown by Leitão et al. (2001b) where parents and offspring had similar aneuploidy levels without any contaminant treatments.

Cross and Rebordinos (2003) studied genotypic consequences of heavy metal contamination and showed that the pressure of marine contamination by cadmium, iron and zinc was associated with higher mean number of alleles per locus and lower heterozygosity in Crassostrea angulata populations. Cadmium is known to induce structural and numerical chromosome aberrations in other species and there is considerable evidence for its clastogenicity. It has been shown to induce DNA strand-breakage, chromosomal aberrations and sister chromatid exchanges in various mammalian cells in vitro (Ochi et al., 1984; Howard et al., 1991; Coogan et al., 1992); but at much higher levels (> $1 \mathrm{mg} \mathrm{L}^{-1}$ ) than the ones we tested in vivo.

\subsection{Hemocyte parameters}

Several hemocyte parameters presented differences after 21 and 66 days of contact with cadmium. The percentage of esterase positive cells increased at $500 \mathrm{ng} \mathrm{L}^{-1}$ cadmium after 21 days of contact, in contrast with a previous study which showed no effect of cadmium on acetylcholinesterase in Mytilus galloprovincialis (Najimi et al., 1997). Peroxidase activity also increased, which could have been related to the esterase increase. Several hemocyte parameters (hemocyte mortality, peroxidases and phagocytosis) increased significantly after 21 days, with or without cadmium, and then decreased after this sampling date. Hence, maintaining oysters in laboratory conditions may itself modify hemocyte parameters. However, a sufficient maintenance time allows parameters to recover their initial values (Russo and Lagadic, 2004). A similar 'recovery' result was reported after diuron contamination but not in laboratory controls (Bouilly et al., unpublished). In previous in vivo studies where correlations were shown between exposure and cell reactions, the Cd concentrations were higher than those used in the present study. For example, $1 \mathrm{mg} \mathrm{L}^{-1}$ cadmium tested on Crassostrea virginica for 2 weeks induced increases in phagocytosis and number of circulating hemocytes (Cheng et al., 1987; Cheng, 1988a, 1988b). The same concentration also decreased hemocyte viability but only after 24 hours contact (Cheng, 1990). Contact with a concentration of 400 $\mathrm{M} \mathrm{L} \mathrm{L}^{-1} \mathrm{Cd}$ induced a decrease in phagocytosis and an increase of number of circulating hemocytes in Mytilus edulis (Coles et al., 1995), but phagocytosis increased at $40 \mu \mathrm{g} \mathrm{L}^{-1}$. However, in Ruditapes philippinarum, no effect of cadmium was found on phagocytosis or superoxide dismutase after 7 days of contact with Cd concentrations ranging from 0 to $450 \mathrm{\mu g} \mathrm{L}^{-1}$ (Matozzo et al., 2001).

Another study reported that cadmium accumulates preferentially in $\underline{C}$. gigas hemocytes from the gills, labial palps and digestive tract walls, rather than in mobile hemocytes (Martoja and Martin, 1985). Therefore, hemocytes from hemolymph may not be a primary zone for cadmium accumulation.

Bivalves can produce metallothioneins (MT) under higher cadmium concentrations. After 21 days

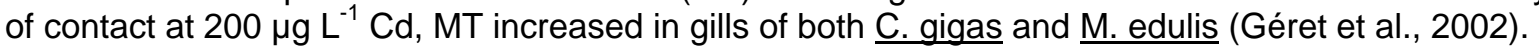
These molecules enter the circulation and are transported to the kidney where $\mathrm{Cd}$ is efficiency absorbed and rapidly degraded (Fowler, 1993).

PO-like activities varied over the time of the experiment but this was not always due to cadmium. Cadmium only increased PO-like activity at 66 days of contact. There are no reports of cadmium

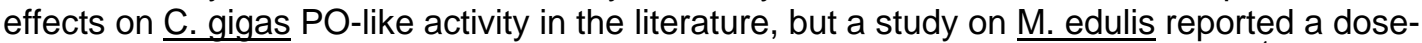
dependent increase of PO-like activity after 7 days contact with 200 and $400 \mu \mathrm{g} \mathrm{L}^{-1}$ of fluoranthen (Coles et al., 1994).

\section{Conclusion}

Our study was designed to provide an integrated assessment of the toxicological impact of cadmium to oysters at two levels: genotoxicity and immunotoxicity. Cadmium caused significant increases in aneuploidy of adult Pacific oyster at concentrations that these animals could encounter in 
polluted environments, but did not affect juveniles in the same way. This heavy metal also led to some significant, but reversible, changes in hemocyte parameters. A decrease in survival time was observed at $50 \mathrm{ng} \mathrm{L}^{-1}$ cadmium but not at $500 \mathrm{ng} \mathrm{L}^{-1}$. At environmental concentrations, therefore, cadmium affects the survival of $\underline{C}$. gigas but only has small effects on its aneuploidy level and hemocyte parameters. Thus, the Pacific oyster does not appear to be highly sensitive to cadmium, probably because it has $\mathrm{Cd}$ detoxification mechanisms. Such mechanisms could explain why large numbers of oysters are present in areas subject to recurrent cadmium pollution.

\section{Acknowledgements}

Part of this research was supported by the Conseil Général of Charente-Maritime, the Région Poitou-Charentes, and the Programme Environnement, Vie et Sociétés from CNRS. We thank R.B. Hamadou for statistical analyses and $\mathrm{H}$. McCombie-Boudry for English editing and constructive comments. 


\section{References}

Auffret, M., Mujdzic, N., Corporeau, C., Moraga, D., 2002. Xenobiotic-induced immunomodulation in the European flat oyster, Ostrea edulis. Mar. Environ. Res. 54, 585-589.

Bebianno, M.J., Serafim, M.A., 1998. Comparison of metallothionein induction in response to cadmium in the gills of the bivalve molluscs Mytilus galloprovincialis and Ruditapes decussatus. Sci. Total Environ. 214, 123-131.

Bouilly, K., Leitão, A., McCombie, H., Lapègue, S., 2003. Impact of atrazine on aneuploidy in Pacific oysters, Crassostrea gigas. Environ. Toxicol. Chem. 22, 229-233.

Bouilly, K., McCombie, H., Leitão, A., Lapègue, S., 2004. Persistence of atrazine impact on aneuploidy in Pacific oysters, Crassostrea gigas. Mar. Biol. 145, 699-705.

Bouilly, K., Leitão, A., Chaves, R., Guedes-Pinto, H., Boudry, P., Lapègue, S., 2005. Endonuclease banding reveals that atrazine-induced aneuploidy resembles spontaneous chromosome loss in Crassostrea gigas. Genome 48, 177-180.

Boutier, B., Chiffoleau, J.F., Jouanneau, J.M., Latouche, C., Philips, I., 1989. La contamination de la Gironde par le cadmium : origine, extension, importance. Rapport scientifique et technique IFREMER, $\mathrm{n}^{\circ} 14$, Nantes, France, $105 \mathrm{p}$.

Boutier, B., Chiffoleau, J.F., Gonzalez, J.L., Lazure, P., Auger, D., Truquet, I., 2000. Influence of the Gironde estuary outputs on cadmium concentrations in the coastal waters: consequences on the Marennes-Oléron bay (France). Oceanol. Acta 23, 745-757.

Cheng, T.C., 1981. Bivalves. In: Ratcliffe, N.A., Rowley, A.F. (Eds.), Invertebrate blood cells. Academic Press, London, pp. 233-299.

Cheng, T.C., 1988a. In vivo effects of heavy metals on cellular defense mechanisms of Crassostrea virginica: total and differential cell counts. J. Invertebr. Pathol. 51, 207-214.

Cheng, T.C., 1988b. In vivo effects of heavy metals on cellular defense mechanisms of Crassostrea virginica: phagocytic and endocytotic indices. J. Invertebr. Pathol. 51, 215-220.

Cheng, T.C., 1990. Effects of in vivo exposure of Crassostrea virginica to heavy metals on hemocyte viability and activity levels of lysosomal enzymes, Vol. Academic Press, San Diego, CA, USA.

Cheng, T.C., Rodrick, G.E., 1975. Lysosomal and other enzymes in the haemolymph of Crassostrea virginica, and Mercenaria mercenaria. Comp. Biochem. Physiol. B 52, 443-447.

Cheng, T.C., Mohandas, A., Sullivan, J.T., 1987. In vivo effects of heavy metals on cellular immunity in molluscs. In: Dorignan, J.V., Harrison, F.L. (Eds.), Physiological responses of marine organisms to environmental stressors, Vol. chap. 6, pp. 59-62.

Coles, J.A., Farley, S.R., Pipe, R.K., 1994. Effects of fluoranthene on the immunocompetence of the common marine mussel, Mytilus edulis. Aquat. Toxicol. 30, 367-379.

Coles, J.A., Farley, S.R., Pipe, R.K., 1995. Alteration of the immune response of the common marine mussel Mytilus edulis resulting from exposure to cadmium. Dis. Aquat. Organ. 22, 59-65.

Coogan, T., Bare, R., Waalkes, M., 1992. Cadmium-induced DNA strand damage in cultured liver cells: reduction in cadmium genotoxicity following zinc pretreatment. Toxicol. Appl. Pharmacol. 113, 227-233.

Cross, I., Rebordinos, L., 2003. Effect of marine contamination on the genetic population structure of the bivalve Crassostrea angulata. Cienc. Mar. 29, 239-250.

De Zwaan, A., Eertman, R.H.M., 1996. Anoxic or aerial survival of bivalves and other euryoxic invertebrates as a useful response to environmental stress - a comprehensive review. Comp. Biochem. Physiol. C 113, 299-312.

De Zwaan, A., Cattani, O., Vitali, G., Cortesi, P., 2001. Influence of incubation conditions on the anoxic survival of marine bivalves. Static and semi-static incubations. Mar. Ecol. Prog. Ser. 211, 169-179.

Ettajani, H., Berthet, B., Amiard, J.C., Chevolot, L., 2001. Determination of cadmium partitioning in microalgae and oysters: contribution to the assessment of trophic transfer. Arch. Environ. Contam. Toxicol. 40, 209-221.

FAO, 2004. Annuaire de statistiques des Pêches 2002. Production de l'Aquaculture. Vol 94/2. Statistiques No. 181 et Pêches No. 67, Rome, 206 pp.

Fowler, B.A., 1993. Mechanisms of kidney cell injury from metals. Environ. Health Perspect. 100, 5763.

Frazier, J.M., 1979. Bioaccumulation of cadmium in marine organisms. Environ. Health Perspect. 28, 75-79.

Gagnaire, B., Renault, T., Bouilly, K., Lapègue, S., Thomas-Guyon, H., 2003. Study of atrazine effects on Pacific oyster, Crassostrea gigas, haemocytes. Curr. Pharm. Des. 9, 193-199.

Gagnaire, B., Thomas-Guyon, H., Renault, T., 2004. In vitro effects of cadmium and mercury on Pacific oyster, Crassostrea gigas (Thunberg), haemocytes. Fish Shellfish Immun. 16, 501-512. 
Géret, F., Jouan, A., Turpin, V., Bebianno, M.J., Cosson, R.P., 2002. Influence of metal exposure on metallothionein synthesis and lipid peroxidation in two bivalve mollusks: the oyster (Crassostrea gigas) and the mussel (Mytilus edulis). Aquat. Living Resour. 15, 61-66.

Howard, W., Leonard, B., Moody, W., Kochlar, T.S., 1991. Induction of chromosome changes by metal compounds in cultured CHO cells. Toxicol. Lett. 56, 179-186.

IARC (International Agency for Research on Cancer), 1993. Berylium, cadmium, mercury and exposures in the glass manufacturing industry, vol. 58, IARC Scientific Publications, Lyon, France. Ivanova, E.P., Kurilenko, V.V., Kurilenko, A.V., Gorshkova, N.M., Shubien, F.N., Nicolau, D.V., Chelomin, V.P., 2002. Tolerance to cadmium of free-living and associated with marine animals and eelgrass marine gamma-proteobacteria. Curr. Microbiol. 44, 357-362.

Jonnalagadda, S.B., Prasada Rao, P.V.V., 1993. Toxicity, bioavailability and metal speciation. Comp. Biochem. Physiol. C 106, 585-595.

Kaplan, E.L., Meier, P., 1958. Nonparametric estimation from incomplete observations. J. Am. Stat. Assoc. 53, 457-481.

Leitão, A., Boudry, P., Thiriot-Quiévreux, C., 2001a. Negative correlation between aneuploidy and growth in the Pacific oyster Crassostrea gigas: ten years of evidence. Aquaculture 193, 39-48.

Leitão, A., Boudry, P., McCombie, H., Gérard, A., Thiriot-Quiévreux, C., 2001b. Experimental evidence for a genetic basis to differences in aneuploidy in the Pacific oyster (Crassostrea gigas). Aquat. Living Resour. 14, 233-237.

Leitão, A., Boudry, P., Thiriot-Quiévreux, C., 2001c. Evidence of differential chromosome loss in aneuploid karyotypes of the Pacific oyster, Crassostrea gigas. Genome 44, 735-737.

Mantel, N., 1966. Evaluation of survival data and two new rank order statistics arising in its consideration. Cancer Chemother. Rep. 50, 163-170.

Martoja, R., Martin, J.L., 1985. Detoxification of cadmium by the oyster Crassostrea gigas (Mollusca Bivalvia). Characterization of a cadmium-binding protein in the zinc and copper-containing amoebocytes. CR. Acad. Sci. III 300, 549-554.

Matozzo, V., Ballarin, L., Pampanin, D.M., Marin, M.G., 2001. Effects of copper and cadmium exposure on functional responses of hemocytes in the clam, Tapes philippinarum. Arch. Environ. Contam. Toxicol. 41, 163-170.

Miramand, P., Pigeot, J., Guyot, T., Fichet, D., 1999. Ecotoxicologie intégrée : de l'espèce à l'écosystème. Océanis 25, 581-608.

Najimi, S., Bouhaimi, A., Daubeze, M., Zekhnini, A., Pellerin, J., Narbonne, J.F., Moukrim, A., 1997. Use of acetylcholinesterase in Perna perna and Mytilus galloprovincialis as a biomarker of pollution in Agadir marine bay (South of Morocco). Bull. Environ. Contam. Toxicol. 58, 901-908.

Ochi, T., Mogi, M., Watanabe, M., Oshawa, M., 1984. Induction of chromosomal aberrations in cultured Chinese hamster ovary cells by short-term treatment with cadmium chloride. Mutat. Res. 137, 103-109.

Pennec, J.P., Gallet, M., Gioux, M., Dorange, G., 2002. Cell culture of bivalves: tool for the study of the effects of environmental stressors. Cell. Mol. Biol. 48, 351-358.

Pigeot, J., Miramand, P., Guyot, T., Sauriau, P.G., Fichet, D., Le Moine, O., Huet, V., 2006. Cadmium pathways in an exploited intertidal ecosystem with chronic cadmium inputs (Marennes-Oléron, Atlantic coast, France). Mar. Ecol. Prog. Ser. 307, 101-114.

Pipe, R.K., 1992. Generation of reactive oxygen metabolites by the haemocytes of the mussel Mytilus edulis. Dev. Comp. Immunnol. 16, 111-122.

Robert, R., His, E., 1985. Combined effects of salinity and cadmium chloride upon embryos and larvae of the Japanese oyster, Crassostrea gigas. Mar. Environ. Res. 15, 303-312.

Russo, J., Lagadic, L., 2004. Effects of environmental concentrations of atrazine on hemocyte density and phagocytic activity in the pond snail Lymnaea stagnalis (Gastropoda, Pulmonata). Environ. Pollut. 127, 303-311.

Scherrer, B., 1984. Biostatistique. Gaëtan Morin, Montréal, Canada.

Sokal, R.R., Rohlf, F.J., 1995. Biometry. Freeman WH \& Company, New York, NY, USA.

Soletchnik, P., Le Moine, O., Goulletquer, P., Geairon, P., Razet, D., Faury, N., Fouché, D., Robert,

S., 2001. Optimisation of the traditional Pacific cupped oyster (Crassostrea gigas Thunberg) culture on the Atlantic coastline: autummal fattening in semi-closed ponds. Aquaculture 199, 73-91.

Thiriot-Quiévreux, C., 1986. Etude de l'aneuploïdie dans différents naissains d'Ostreidae (Bivalvia). Genetica 70, 225-231.

Thiriot-Quiévreux, C., Ayraud, N., 1982. Les caryotypes de quelques espèces de bivalves et gastéropodes marins. Mar. Biol. 70, 165-172. 
Vicente, N., Henry, M., Chabert, D., Riva, A., 1988. Contrôle de métaux lourds danns les écosystèmes littoraux et dans les chaînes alimentaires marines : expériences de contamination par un élément métallique, le cadmium. Océanis 14, 201-223.

Watling, H.R., 1978. Effect of cadmium on larvae and spat of the oyster, Crassostrea gigas (Thunberg). Trans. roy. Soc. S. Afr. 43, 125-134.

Wilkinson, L., 1990. SYSTAT: The System for Statistics. SYSTAT, Evanston, IL, USA.

Zaroogian, G.E., Morrison, G., 1981. Effect of cadmium body burdens in adult Crassostrea virginica on fecundity and viability of larvae. Bull. Environ. Contam. Toxicol. 27, 344-348. 
Table 1 Values and standard deviation of hemocyte parameters and PO-like activity with time and cadmium concentrations. Values are means of four replicates.

\begin{tabular}{|c|c|c|c|c|c|c|c|c|}
\hline Time (days) & Concentration & Mortality & Esterases & AP & Peroxidases & Phagocytosis & Granulocytes & $\mathrm{PO}$ \\
\hline 0 & 0 & $5.6 \pm 2.8$ & $6.2 \pm 4.2$ & $54.2 \pm 9.9$ & $9.2 \pm 5.5$ & $31.8 \pm 17.7$ & $7.6 \pm 2.5$ & $0.9 \pm 0.2$ \\
\hline \multirow[t]{3}{*}{4} & 0 & $6.0 \pm 4.2$ & $3.9 \pm 3.6$ & $48.4 \pm 9.6$ & $3.9 \pm 3.2$ & $31.3 \pm 20.0$ & $6.8 \pm 3.2$ & $0.9 \pm 0.1$ \\
\hline & $50 \mathrm{ng} \mathrm{L}^{-1}$ & $8.7 \pm 4.2$ & $4.9 \pm 2.1$ & $60.5 \pm 6.3$ & $4.9 \pm 2.3$ & $31.7 \pm 20.4$ & $9.2 \pm 1.5$ & $0.7 \pm 0.2$ \\
\hline & $500 \mathrm{ng} \mathrm{L}^{-1}$ & $9.6 \pm 2.4$ & $8.7 \pm 8.1$ & $65.5 \pm 11.7$ & $7.9 \pm 5.3$ & $24.9 \pm 14.6$ & $10.9 \pm 3.4$ & $0.9 \pm 0.1$ \\
\hline \multirow[t]{3}{*}{21} & 0 & $10.9 \pm 4.4$ & $40.8 \pm 13.7$ & $80.5 \pm 10.0$ & $33.5 \pm 12.9$ & $44.7 \pm 10.9$ & $5.9 \pm 2.1$ & $0.7 \pm 0.1$ \\
\hline & $50 \mathrm{ng} \mathrm{L}^{-1}$ & $19.3 \pm 12.4$ & $29.6 \pm 13.2$ & $81.5 \pm 6.7$ & $25.6 \pm 2.8$ & $23.2 \pm 11.9$ & $9.1 \pm 2.7$ & $0.6 \pm 0.1$ \\
\hline & $500 \mathrm{ng} \mathrm{L}^{-1}$ & $10.3 \pm 1.8$ & $67.8 \pm 6.0$ & $81.2 \pm 4.8$ & $49.9 \pm 6.1$ & $54.1 \pm 4.9$ & $8.6 \pm 1.5$ & $0.6 \pm 0.2$ \\
\hline \multirow[t]{3}{*}{42} & 0 & $3.6 \pm 1.4$ & $6.2 \pm 4.8$ & $60.6 \pm 13.2$ & $14.1 \pm 5.6$ & $23.8 \pm 15.4$ & $4.8 \pm 2.4$ & $1.2 \pm 0.2$ \\
\hline & $50 \mathrm{ng} \mathrm{L}^{-1}$ & $3.3 \pm 1.0$ & $10.8 \pm 6.8$ & $62.2 \pm 19.7$ & $14.5 \pm 6.5$ & $37.4 \pm 21.1$ & $2.7 \pm 0.3$ & $1.2 \pm 0.2$ \\
\hline & 500 ng $\mathrm{L}^{-1}$ & $4.3 \pm 2.1$ & $7.9 \pm 4.9$ & $77.9 \pm 6.7$ & $14.7 \pm 5.4$ & $38.5 \pm 24.1$ & $3.3 \pm 0.9$ & $1.3 \pm 0.0$ \\
\hline \multirow[t]{3}{*}{66} & 0 & $8.9 \pm 5.8$ & $21.8 \pm 13.4$ & $27.2 \pm 13.5$ & Not analyzed & $42.8 \pm 24.5$ & $5.5 \pm 1.1$ & $0.1 \pm 0.3$ \\
\hline & $50 \mathrm{ng} \mathrm{L}^{-1}$ & $5.9 \pm 2.6$ & $23.3 \pm 18.4$ & $18.2 \pm 10.1$ & Not analyzed & $52.8 \pm 34.9$ & $4.6 \pm 2.7$ & $0.3 \pm 0.3$ \\
\hline & $500 \mathrm{ng} \mathrm{L}^{-1}$ & $6.3 \pm 3.4$ & $15.6 \pm 2.6$ & $19.8 \pm 7.9$ & Not analyzed & $36.2 \pm 6.6$ & $9.0 \pm 3.0$ & $0.8 \pm 0.3$ \\
\hline
\end{tabular}




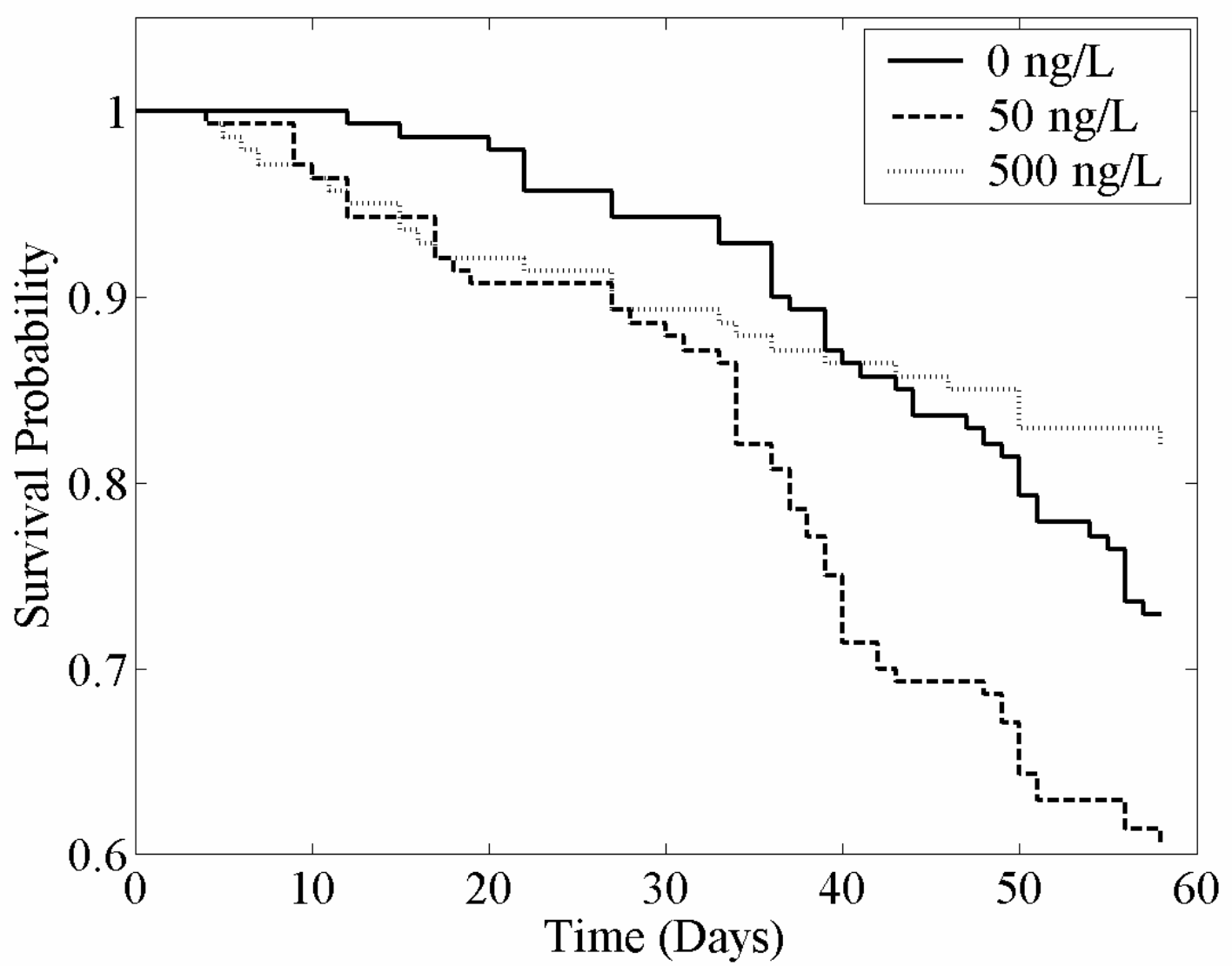

Fig. 1. Survival probability of the adult oysters Crassostrea gigas exposed to different cadmium concentrations (0, 50 and $\left.500 \mathrm{ng} \mathrm{L}^{-1}\right)$. 


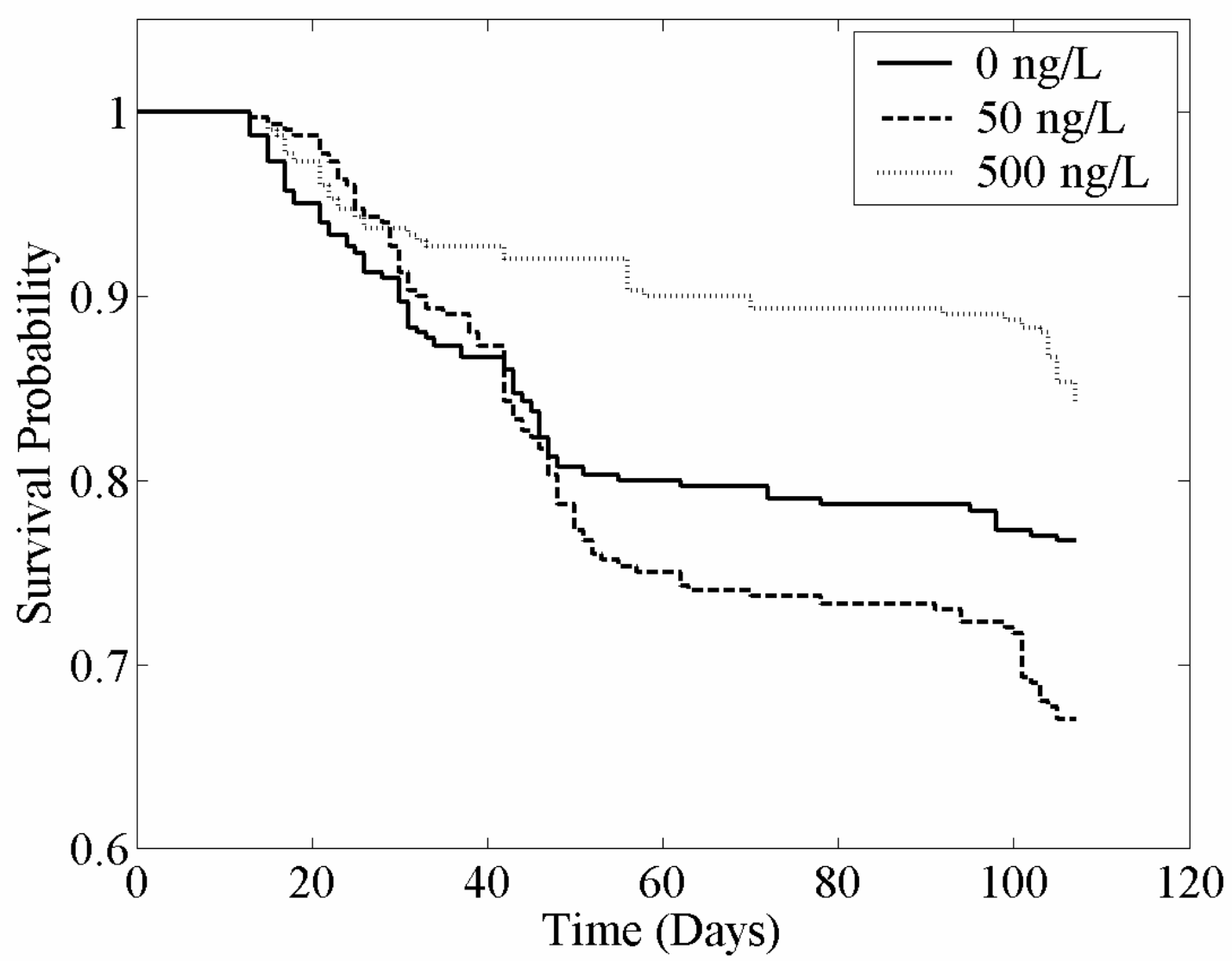

Fig. 2. Survival probability of the juvenile oysters Crassostrea gigas exposed to different cadmium concentrations (0, 50 and $\left.500 \mathrm{ng} \mathrm{L}^{-1}\right)$. 


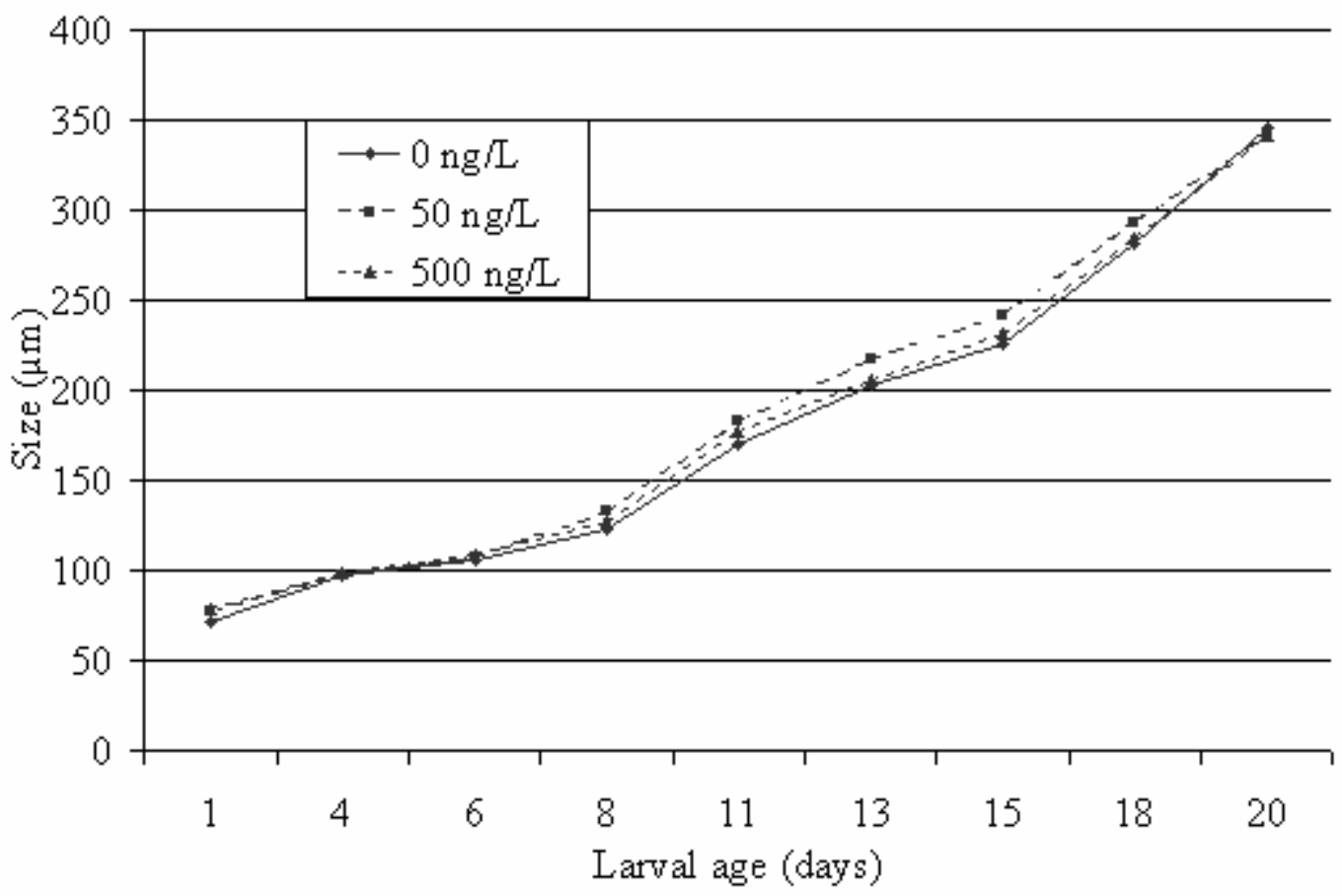

Fig. 3. Size $(\mu \mathrm{m})$ of larvae bred from parental oysters Crassostrea gigas previously exposed to different cadmium concentrations $(0,50$ and 500 ng L-1). 


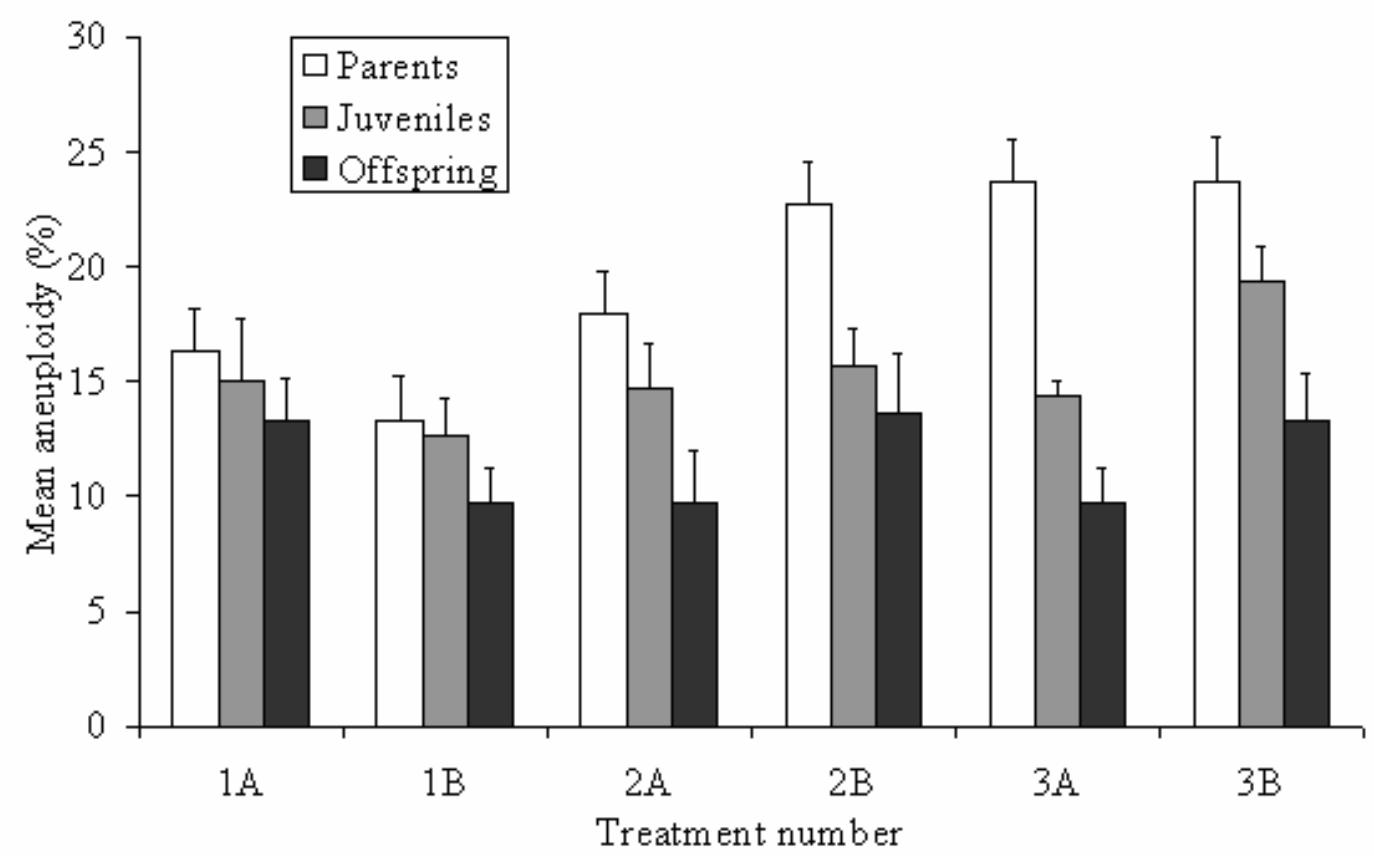

Fig. 4. Mean percentage aneuploidy of adult and juvenile oysters Crassostrea gigas exposed to different cadmium concentrations: treatments $1 \mathrm{~A}, 1 \mathrm{~B}$ (control $0 \mathrm{ng} \mathrm{L}^{-1}$ ), treatments $2 \mathrm{~A}, 2 \mathrm{~B}$ (50 ng L ${ }^{-1}$ ) and treatments 3A, 3B (500 ng L ${ }^{-1}$ ), and of the offspring. Bars indicate standard deviation of the mean. 


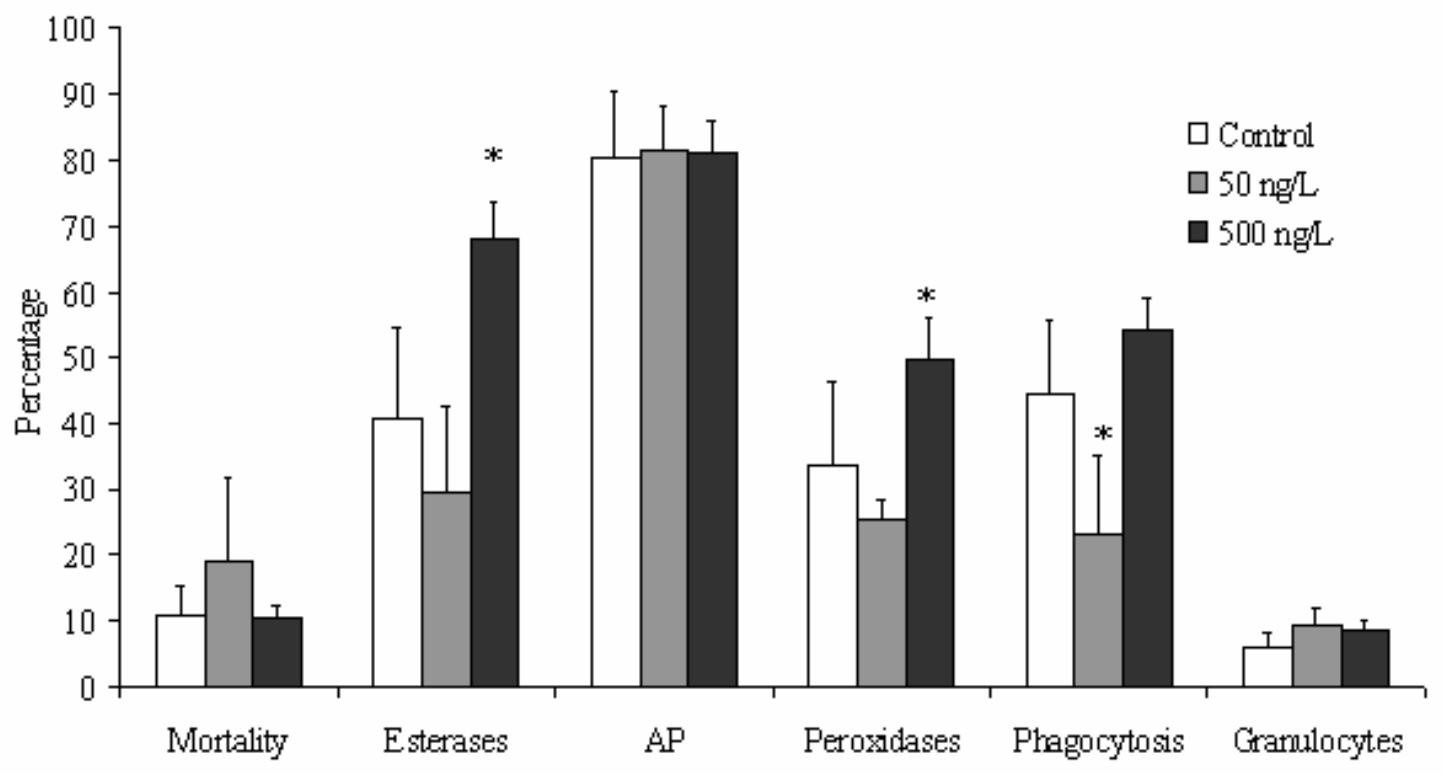

Fig. 5. Evolution of hemocyte parameters in Crassostrea gigas after 21 days of contact with different cadmium concentrations $\left(0,50\right.$ and $\left.500 \mathrm{ng} \mathrm{L}^{-1}\right)$. ${ }^{*}=\mathrm{P}<0.05$. 


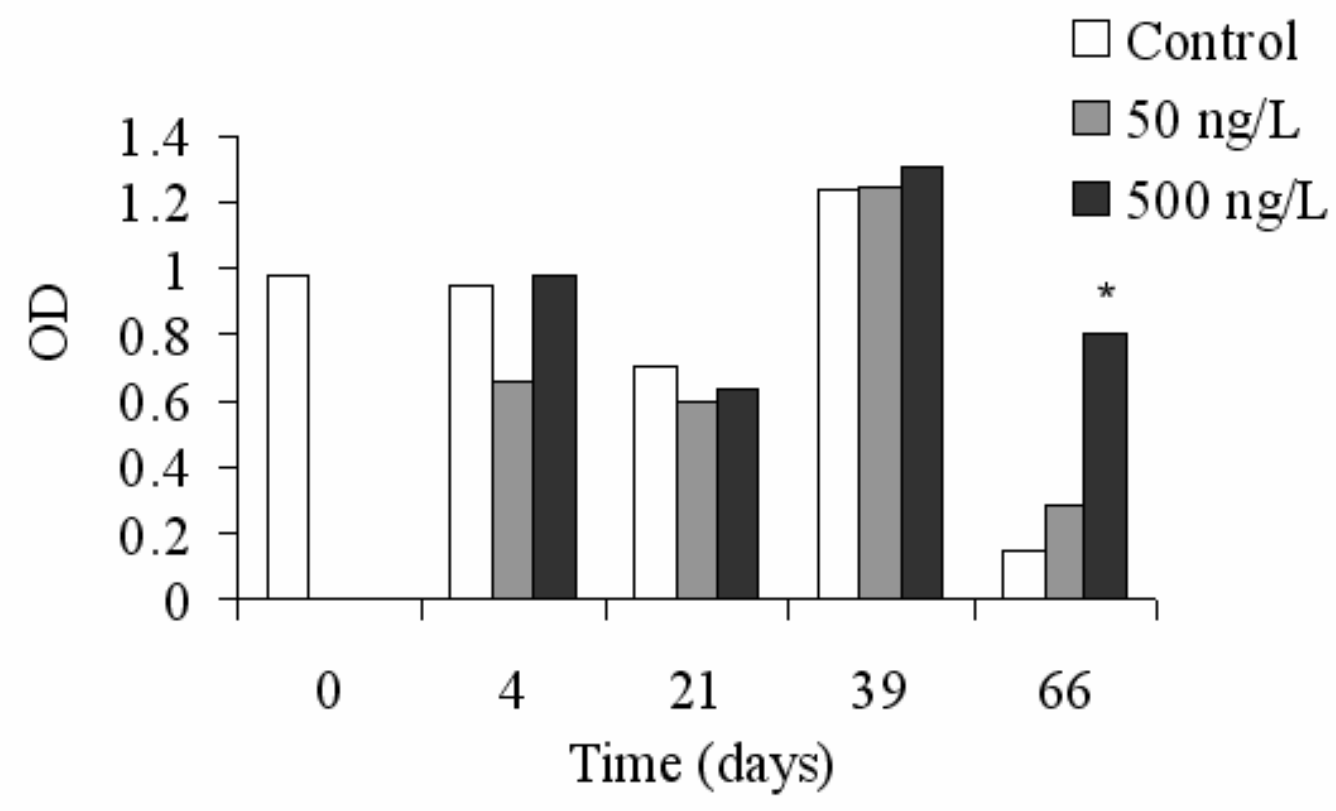

Fig. 6. Evolution of PO-like activity in Crassostrea gigas with time in different cadmium concentrations $\left(0,50\right.$ and $\left.500 \mathrm{ng} \mathrm{L}^{-1}\right) . *=\mathrm{P}<0.05$. 